\title{
ENTREVISTA CON RENÉE DE LA TORRE CASTELLANOS
}

\section{Pamela Jorquera ${ }^{1}$}

Durante el primer semestre del año en curso, el Programa de Pós-graduação em Antropologia Social (PPGAS) de la Universidad Federal de Rio Grande del Sur, recibió la visita de la Profesora mexicana, Renée de la Torre Castellanos. Renée, doctora en Antropología Social por la Universidad de Guadalajara y profesora e investigadora del CIESAS en la ciudad de Guadalajara México, ha tenido como principal interés la comprensión de las culturas e identidades urbanas en un contexto contemporáneo, enfatizando el estudio de las transformaciones en las creencias y prácticas religiosas. Esa experticia permitió que, durante su estadía en el PPGAS, dictará el tópico especial "Debates teórico-metodológicos sobre a mudança religiosa na América Latina”. Curso donde pudo discutir y reflexionar con estudiantes de magister y doctorado del Programa interesados en el estudio de dicho tema. Si bien sus intereses se han centrado en dichos temas, Renée también ha desarrollado el estudio a través de imágenes en sus investigaciones. En ese contexto visitó el Núcleo de Antropología Visual (Navisual), invitada por la profesora Dra. Cornelia Eckert (coordinadora Navisual). En dicha oportunidad conversó con el equipo sobre las implicancias del estudio con imágenes y presentó sus trabajos realizados en torno al tema de la religión. Fue ahí cuando se me encomendó la tarea de profundizar algunos temas discutidos y de aprovechar de abarcar otros de interés para el equipo y el programa, tarea que constituyó una honra para mi.

\section{Entrevista}

Pamela: La verdad es que pensé en la entrevista, en unos dos o tres temas, sumado al que ahora nos recomendó Ronaldo, principalmente para conocer más de tu estudio sobre las imágenes; uno porque quiero saber más sobre el estudio de ellas, y dos porque considero que hay que reflexionar un poco más sobre eso, entonces me gustaría conocer tu visión. Lo

\footnotetext{
${ }^{1}$ Universidade Federal do Rio Grande do Sul, Brasil.
} 
primero es que puedas profundizar un poco más en esto del problema de la vinculación teórica... incluso lo anoté, de que no estabas muy de acuerdo con la teoría.

Renée: Fíjate, que lo de las imágenes, yo creo que ahí es un poco... un tema complicado, como que por un lado hay toda una teoría de plantear que la imagen es de alguna manera el vaciamiento del símbolo y del signo y es como este referente más significante, que tiene mucho más carga, menos carga de significado. En toda la teoría... semiótica, se hace, incluso... se hace estos anuncios de decir; "estamos entrando en la era de la imagen y se está perdiendo el símbolo" y que estamos en una sociedad, donde la imagen está tomando un lugar muy importante, en las formas de trasmisión cultural, pero donde la imagen está sustituyendo al símbolo, y donde el símbolo aparecía como el sustrato de riqueza cínica cultural. Entonces puede parecer una paradoja apostarle al estudio de la imagen como tal, pero lo que nosotros, o yo he encontrado, y otros colegas también, es que la imagen no es solamente significante, sino que es también significado, y que la imagen, sobretodo, incluso por ese papel tan importante que está teniendo en la sociedad actual, porque casi todos los medios de comunicación... ponderan la imagen como lenguaje; o sea el video clip, el cine, el video, en internet incluso, hay mucho más lenguaje de imágenes que lenguaje escrito verbal, y de alguna manera ésta así como que suplanta al otro y, sin embargo por otra parte, yo creo que también, es la manera de acceso, otra vez al símbolo y en la sociedad actual. A pesar de que, muchas teorías sobre todo francesas, a los franceses les gusta mucho decir que lo nuevo va a suplir lo antiguo, les encanta entrar en estas visiones apocalípticas, en donde... como si fuera la guerra de las galaxias, una cosa, va a dejar fuera a la otra. Lo que si tienen es una enorme capacidad para olfatear, las nuevas emergencias, que yo creo que eso nos marca también pistas de indagación, entonces desde siempre los franceses como que nos van de alguna manera marcando las pautas de lo emergente. Sin embargo, casi siempre, nos plantean que eso nuevo está cambiando totalmente, los regímenes que conocemos y que están supliendo las formas tradicionales, y a lo largo de la historia, hemos visto que las formas tradicionales no han sido suplidas, o sea lo nuevo no ha... eliminado lo tradicional, y eso yo creo que es muy importante, entonces en una sociedad, en donde es cierto que la imagen viene de alguna manera a colocarse como un lenguaje muy importante de nuestra sociedad, lo que no sucede es que la imagen realmente le este quitando el 
sustrato símbolo al símbolo, sino que en si mismo se convierte también... esa imagen incluso de la publicidad, del marketing muchas veces, llega a convertirse en símbolos densos. En términos de religiosidad, lo que hemos estado atendiendo, yo creo que es parte de eso, había muchos, incluso, en las teorías de religión que decían que...

Pamela: Disculpa Renée ¿cuando hablas de... "en términos densos” te refieres a Geertz, en la interpretación?

Renée: No...bueno... puede ser, pero no, al acto de interpretar sí, no... a la densidad semiótica, que está presente y practicada en las imágenes y los signos, pero no en el acto de la investigación, que es a lo que se refiere Geertz. Si no, a tramas densas que están ahí, cada vez mayor, o sea cada vez el símbolo para mí, no que antes no lo fuera, pero siempre ha sido una encrucijada, y siempre es una encrucijada donde se están de alguna manera disputando, distintas memorias, distintas maneras de pertenecer, distintos roles funcionales, distintas necesidades que se dan al símbolo, entonces en lugar de que... a mi manera, o lo que yo encuentro, en lugar que se estén vaciando de significados... al revés, las tramas se vuelven mucho más densas, porque es... por ejemplo es lo que platicaba el otro día... o la exposición de a vestir santos, es la apuesta ¿no? El símbolo, aunque, digamos que los clásicos pueden decir... “¡No, bueno! es que si se le dan estos nuevos significados quiere decir que los están vaciando, o que lo están de alguna manera transformando", pero es que lo nuevo no desplaza, a las memorias tradicionales, ni al entramado histórico, de la lucha por el símbolo. Esos símbolos se vuelven cada vez más densos, por un lado...

Pamela:;Claro, se complejizan!

Renée: Se complejizan, e incluso establecen tensiones, conflictos, pero también maneras de solucionar lo nuevo. Cuando estas teorías postmodernas plantean continuamente metáforas como: cambio de era, vaciamiento, sin significado. Los contenidos, de alguna manera, viajan, estallan, se desmoronan, se hacen migajas, pierden sus fuerzas, o sea todas estas 
metáforas, están hablando de que salen del símbolo, y lo dejan como un significante vacío, es decir, una imagen, eso sería una imagen. Y lo que atendemos, al menos en el estudio de la religión, es que estos símbolos al contrario, son de alguna manera el recipiente de las memorias, pero de las memorias en tensión, de las memorias en donde hay toda una resistencia frente a la imposición colonial, y una resistencia que se ha mantenido en siglos, y que ha permitido mantener tradiciones: sincréticas, renovadas, hibridas, como les quieras llamar, pero ahí están. Y al mismo tiempo, es también, el lugar donde lo nuevo, busca tener una representación, y busca también construirse un linaje, que es lo que le da legitimidad.

Pamela: Claro, porque lo nuevo, no necesariamente tiene legitimidad, no está validado.

Renée: Exactamente y busca en esos símbolos construirse un linaje, pero al mismo tiempo también busca establecer lo nuevo dentro del símbolo y reconocerse dentro del símbolo. Entonces ese tipo de hecho social, que tiene mucho que ver con las estéticas, porque hay una lucha a través de las estéticas, de posicionarse en el símbolo, y en lugar de que, otra vez, de que la estética fuera el vaciamiento del símbolo, lo que están haciendo más bien es reincorporándose, en las tramas, y en las tramas históricas del símbolo, esa es un poco la apuesta. Bueno, entonces, en los dos trabajos que les platiqué el otro día, el de vestir santos y también el que hicimos sobre los rituales de tradicionales, esa es la apuesta y era haber notado, qué es la estética, o el estilo, la estilística, es también contenido y es sobre todo, una manera de habitar, practicar el símbolo, y de ritualizar el símbolo, o sea ritualizar el símbolo, también está ligado con una manera de construir la relación entre lo sagrado y lo profano, es decir sacralizar el símbolo ¡no vaciarlo!. Entonces, los santos católicos o los santos seculares... lo que nosotros vemos no es un vaciamiento de los santos, es cierto que hay santos que se ponen más de moda, hay santos que pasan de moda, o sea, todo eso es cierto, pero eso siempre ha sido. Y más bien lo que encontramos es que a pesar de que supuestamente como decía Bordieu, existe un monopolio erudito de las formas religiosas establecidas en el campo religioso, a nivel de la religiosidad popular, de como festejar a las Vírgenes y a los santos, no es esa capacidad de gestión erudita, la que gestiona el símbolo, sino es realmente la practica popular, la que le da sentido. Y es en el ritual donde estas apropiaciones, se escriben, y transcriben y transforman, las ageografías institucionales, en 
ageografías populares ¡no! O sea, el Santo que por ser mártir de la cristiandad, se convierte en el que ayuda a pasar la frontera... Y es el mito el que reescribe, y transforma esa geografía que les queda muy lejos, o ajena, o que no les significa mucho, en una geografía milagrosa que es la que realmente renueva al símbolo en el ritual, o sea la gente va a Santo Toribio Romo, recién canonizado por la iglesia católica, como mártir de la guerra Cristera, eso fue en el 2000, actualmente, es el Santo católico de la región, que va de Jalisco a Estados Unidos más importante ¿por qué? Porque los migrantes generaron el mito de que él se aparece en la frontera, y los ayuda a pasar la frontera, les da la (...) cuando tienen problemas, él les presta dinero y se aparece, cuentan los mitos que se aparece constantemente en la frontera, ese mito no lo produjo la parte erudita de la iglesia, no tiene que ver con el monopolio del sacerdote, el sacerdote lo aprovecha para que la gente vaya a su capilla, pero siempre va a decir "este mito no es nuestro", dice "es mito popular" y eso no está vaciando su símbolo ¡al revés! le está metiendo en una trama muy compleja, de una realidad actualizada. Que no está vaciando al símbolo, sino al revés al ritualizarlo, practicarlo, llevarlo consigo, cargarlo para refundar, incluso tradición, territorio y continuidad de lo que son en Estados Unidos, lo está al revés haciendo un símbolo con las encrucijadas de la tradición y de lo que renueva. Y eso está sucediendo en muchas de las imágenes, tanto en las imágenes, que como te digo, ya eran imágenes digamos canonícas de la iglesia, pero también en la invención de imágenes seculares ¿no? Que ahí está la Santa Muerte, Juan Soldado, Gauchito Gil...

Pamela: ¿donde se densifica, se complejizan?

Renée: Claro y ahí también vuelven a construir, en esa imagen, la densidad del símbolo, ¿Cómo llegar a eso?, habría que captarlo por la propia imagen, porque también esos contenidos se expresan, se expresan en estrategias estilísticas; ponerle tal o cual traje, ponerle un arma, cambiarle el rostro, cambiarle el material con que está hecho, hacerlo blanco o negro, ponerle barba o hacerlo lampiño, que parezca más Indio, o que parezca más español, todos esos arreglos de estética, en realidad son los que muestran las estrategias de apropiación simbólica, entonces no son superficiales, sino que están ahí, para decir este símbolo en este momento que está, representa tal cosa, y nos representa a nosotros. Vestir a 
la Virgen de Guadalupe Indígena Militar del Ejército Zapatista, tiene una condensación histórica, política enorme, no están vaciando al símbolo.

Pamela: yo como investigadora ¿cómo puedo estar atenta, de no pasar por alto el hecho de que la Virgen de Guadalupe, ahora haya sido re simbolizada, por ejemplo, por el Ejercito Zapatista?

Renée: Yo creo que eso es un poco desmitificar que eso que ves es insignificante, jeso es lo primero! porque existe esa tendencia a decir "oye el que aparezca así, eso es insignificante" no, no es insignificante. Lo primero es asombrarte, y decir, si algo se está practicando. Qué es eso lo que yo digo, aunque parezca risible, aunque parezca una práctica absurda, aunque parezca una práctica, si se está practicando, es porque algún elemento de conquista y de importancia de sentido hay detrás. Por ejemplo: la religión en torno a Maradona, tú te puedes reír, tú puedes decir, pero eso es un chiste, es una broma, eso no tiene ningún sentido... y yo digo, más bien hay que ver si ya tiene cien mil seguidores y si cien mil gentes decidieron, aunque fuera como broma empezar a practicarla, empezar a generar ese ritual, esas gentes supongo que algún significado importante le estas dando, nadie practicamos nada, no más porque si, aunque para los ojos de otros parezca una broma, o parezca realmente algo sin ton ni son... El que al inicio empezaran gentes vestidas de blanco, a hacer un ritual en las pirámides a cargarse de energía, y que ahora sean millones de personas, algo nos tiene que querer decir... ¿no?. Aunque para otros puedan decir "son una bola de locos, no sé, hippies que inventaron una cosa estúpida, que es cargarse de energía solar". Pero el significado no está ahí, entonces hay que ir a ver realmente, yo creo atender ¿Cómo se están practicando, esos símbolos y esos rituales que aparentemente ¡sí! Parecen que no son relevantes. Eso es lo primero que yo diría, y no pensar que lo que nos parece descabellado, es descabellado.

Pamela: Suena tan dificil...

Renée: Sí, pero mucha gente pudiera decir "pero qué voy a estudiar a que mucha gente se agarre en una mona de huesos y le establezcan un culto", y después esa mona de huesos, 
esa Santa Muerte crece, y el culto ya es un culto enorme... Pues tenemos que aprender, por qué se convirtió en símbolo, y como es practicado para ser un símbolo, no es nada más una imagen.

Pamela: ¿Y eso se hace, conociendo a las personas, conversando con ellas?

Renée: Yo digo que primero es aprender las prácticas y ahí le doy mucha importancia al sentido mismo de la práctica y que el sentido, en realidad, se atiende normalmente en el entramado de lo que es práctica. Hay un sentido que es el sentido de lo que se practica y ahí se genera sentido, hay otro que es el sentido del que alguien te puede narrar ¿Cuál es su intensión al hacer eso? O, realmente ¿cual es el discurso? ¿Cuál es lo que le representa? Pero yo creo que los dos están presentes, el sentido en sí y el sentido para sí, y a veces en el sentido practicado, se construyen o se generan, también ciertas narrativas, que muchas veces, ni siquiera son las del individuo conscientemente, o sea ¿Qué pasa cuando distintas subjetividades, con distintas producciones de identidad de identificación, se conjuntan en una misma ceremonia? Mas allá de la intensión de esa que representa cada uno, también construyen un sentido en conjunción. Por ejemplo; en una romería, en una peregrinación, por un lado esta, el significado que tiene para cada uno de los que peregrina y ahí vas a encontrar obviamente sentidos colectivos. Pero dentro de esos sentidos colectivos va a haber varios sentidos colectivos y la conjunción de esos sentidos colectivos, de estar juntos, de practicar un espacio diverso y de practicarlo unidos también construye un nuevo sentido.

Pamela: Eso es el símbolo para sí, y en sí.

Renée: Yo digo que; uno es acercarte a nivel de las prácticas y tratar de identificar que se está practicando por distintos actores y en la suma de esos distintos actores, agentes ¿Qué significa, ese performance, es el ritual?. Entonces una es observar y la otra es acercarte a preguntar. Creo que las dos cosas metodológicamente se tienen que hacer, y que una no es suficiente en sí misma, o sea necesitas las dos. 
Pamela: Tú también hablabas mucho del trabajo entre diferentes disciplinas, el trabajo ecléctico. Este... "el mirar y acercarte a preguntar” ¿tiene que ser entre un grupo o hay algún privilegio de algún conocimiento, de alguna disciplina por sobre otra?

Renée: Yo, como tuve una escuela no ortodoxa, yo vengo de comunicación, y a mí en comunicación un maestro que me marcó mucho, que se llama Don Jorge González, nos decía esta frase "según el sapo la pedrada" y para mí ha sido la medida, o la medida de la decisión que yo tomó. Y "según el sapo la pedrada" nos explicaba, que si tú tienes ahí un sapito chiquito en frente y tú quieres con una roca matar al sapo, nunca lo vas a matar. Si tú tienes un sapote y tú quieres con una cervantina querer pegarle al sapote, no le vas a hacer ni media... Pues yo creo que uno tiene que medir el sapo que tiene en frente, y medirlo en términos de tamaño de escala, todas nuestras investigaciones también tenemos que tener una idea, de que escala es la que queremos o incluso de cómo vamos a combinar escalas. El método es bueno dependiendo de la escala que va, y la otra cuestión es ¿cómo se mueve el objeto que vamos a estudiar? Creo que las dos cosas las tenemos que percibir, para poder decidir entonces ¿Cuál debe ser la técnica?, pero también los conceptos que son los más adecuados para trabajar con tal objeto.

Pamela: ¿El concepto es cómo se mueve?

Renée: El concepto, yo lo tomo también, otra vez digo que mis profesores. Yo tenía un profesor Raúl Fuentes que decía "no hay nada más práctico que un buen concepto" y nos planteaban y yo lo tomo así, que un concepto es como un anteojo, y que obviamente tenemos que tomar una buena decisión sobre el anteojo, que nunca tomemos un concepto que no nos permite ver claramente lo que queremos ver y que lo estemos enfocando y que le estemos poniendo lentillas y lentillas. Los conceptos nos hacen ver, o no ver, ciertas realidades. Algo que yo frecuentemente les digo a los alumnos por ejemplo es "si yo te digo a ti escala la ventana y ve las identidades tú no ves nada". No son realidades, uno tiene que construir los observables, esos observables son los conceptos, los que nos van a hacer, a través de tener las definiciones conceptuales, saber entonces como llevar realmente a técnicas que nos permitan observar esos fenómenos. Si yo te digo "salte a un desfile y 
dime, hazme un registro de la lucha de clases", ¡tú no ves lucha de clases!. Ese es un concepto, pero ese concepto bien trabajado, te va a llevar a ver que ciertos contingentes que llevan, portan ciertos emblemas, que tienen tales ideologías y tiene una serie de demandas están realmente objetivando una lucha de clases. O ve a ver un movimiento de masas, no ve a nadie, nadie ve movimientos de masa, ni nadie vemos identidades, ni nadie vemos, incluso, no vemos religiosidades. Entonces para mi, ese es el concepto. Y si el concepto no lo tenemos bien afinado pues no nos va permitir enfocar bien y ver la realidad. Como todo, si me pongo estos lentes para ver de lejos no veo nada, son para leer... y cada vez más necesitamos miradas bifocales. También los lentes son bifocales, por algo. Yo no puedo tratar de ver una realidad abarcativa con una lupa de aumento, lo voy a ver distorsionado. Si me pongo también unos lentes para ver de lejos, para ver de cerca, no puedo tener claridad para leer de cerca. Para mí, esos son los conceptos. Entonces en ese sentido, hay que combinarlos, hay que combinarlos exactamente para poder obtener casi siempre una mirada bifocal. La mayoría de los fenómenos hay que tratarlos de ver en su particularidad, pero también dentro de un concepto y para eso necesitamos teorías, miradas bifocales y obviamente, también, metodologías que nos permitan "pegarle a ese sapo" dependiendo del tamaño que tenga ese sapo. Esa son mis medidas, ya muy en el sentido común de como afinar los instrumentos, y yo creo que antes que nada la investigación, tiene que tener un sentido práctico, del producir con instrumentos.

\section{Pamela: ¿Práctico en qué sentido?}

Renée: Práctico de tomar las decisiones apropiadas para poder llevar a cabo la producción del conocimiento, o sea no quedarte en ese nivel de "yo defiendo ultranza que así lo hace", "yo me dedico toda la vida a hacer historia de vida y soy especialista en historia de vida" o "yo me dedico únicamente al concepto de Luhmann y soy el promotor de Luhmann a ultranza" ¿y cuál es el sentido práctico de eso?

Pamela: ¿Qué repercusión tiene? 
Renée: ¿Qué producción de conocimiento estas... inicialmente te está llevando a eso? O sea, yo creo que el objetivo que tenemos los investigadores académicos, es la producción del conocimiento... Y el conocimiento no es producción de discursos.

Pamela: Eso te iba a preguntar, en el fondo producción de conocimiento ¿pero conocimiento de que tipo?

Renée: Conocimiento del hecho y de la realidad social.

Pamela: ¿Qué este en relación?

Renée: ¡Sí!, de tú objeto de investigación que te planteas o sea, puede ser la realidad Histórica, puede ser la realidad Sociológica, puede ser la realidad Cultural. A la que habitualmente la ubicamos más como Antropológicos, o sea la realidad del pensamiento, pero no que sea la defensa de tal o cual tipo de saber, únicamente por el saber, y no por lo que tienes que aprender a estudiar por ese saber, es decir el saber en función de ser un lente para entender la realidad... no en sí misma, no la técnica por la técnica, o la teoría por La teoría.

Pamela: Renée, relacionado pero pasando a otro tema, que también me quedó dando vueltas después de las conversaciones que hemos estado haciendo, recuerdo que tú dijiste, que te considerabas una Etnógrafa y no una Antropóloga ...

Renée: Porque yo no tuve formación de Antropóloga...

Pamela: ¿Solamente por eso, o ves otras diferencias entre...?

Renée: Hay más bien, te digo yo no tengo una escuela, un dominio sobre las escuelas de Antropología y la práctica de la Etnografía la aprendí en la práctica, en un sentido práctico de la Antropología. 
Pamela: Aprender haciendo.

Renée: Exactamente, entonces sí a mi tú me dices; "a ver dame una clase... sobre la historia de la Antropología " yo no te puedo dar esa clase, estoy fuera de eso.

Pamela: ¿Y eso sería la diferencia entre Etnografía y Antropología?

Renée: Lo que pasa es que yo utilizo la Etnografía a través, dentro de otras técnicas utilizo; la Geografía, utilizo la Demografía, utilizo el análisis del discurso, utilizo el registro de la imagen, utilizo diversas análisis semióticos, en eso fui mucho más formada en el análisis semiótico, entonces distintas herramientas, no únicamente que eran las propias del campo de la Antropología, ni llegué a la Antropología desde la Antropología. Yo me siento muy marcada por lo que fue mi formación de Comunicóloga de sobre todo atender las mediaciones culturales en la producción cultural y creo que esa es una distinta manera de mirar, que nos enseñaron desde la Comunicación. Yo me acuerdo que otros de mis maestros Jesús Martin Barbero en su reflexión, para definir aquello que también no es una disciplina, la Comunicación, sino la suma de distintas disciplinas para entender, un objeto que es la Comunicación y siempre fue eclética, los estudios de la Comunicación, por eso se llaman Ciencias de la Comunicación, no hay una Ciencia de la Comunicación. Yo creo que eso me marca, o sea yo atiendo desde esa posibilidad de incorporar Ciencias e incorporar y atender el hecho social como un hecho mediado, por distintas instancias, no solamente por una, y creo que eso marca mi manera de acercarme a la investigación, y que esta más marcada... por mi escuela de Comunicación que por la Antropología.

Pamela: ¿Y en términos de conocimientos, crees que haya una diferencia entre lo que tú puedes contribuir, desde Comunicóloga a lo que se puede contribuir desde la Antropología?

Renée: Yo creo que ha habido acercamientos desde la Antropología a la Comunicación y también la Comunicación empezó, a partir de los años 90, a incorporar la Etnografía sobre todo cuando eran los estudios sobre la recepción, que ahí se abrió, antes era los estudios 
sobre lo que se producía y como además la producción mediática en realidad generara la cultura y ese objeto se desplazó luego hacia la recepción y luego hacia las mediaciones. Yo creo que ahí fue un importante cambio en la mirada del objeto de la comunicación, que fue de alguna manera planteada por Jesús Martin Barbero de aprender la comunicación y la cultura, no a través del objeto, sino de las mediaciones y eso nos permitía exactamente ver por ejemplo; las Mediaciones históricas, las mediaciones de la memoria, las mediaciones en los procesos de recepción y sobre todo sacar la Comunicación de los medios y verlas en las prácticas, yo creo que es lo mismo que yo hago, pero en el plano del estudio de la religión, yo ahí me siento como que mi formación fuerte está ahí, está ahí, de ahí la aprendí, si me siento ahí muy hija de Jesús Martin Barbero en ese sentido.

Pamela: Otro tema, que también me quedó dando vueltas después de la reunión que tuvimos aquí la semana pasada, es el que tiene que ver con el estudio de las imágenes y los aspecto éticos. Porque hay una discusión por ejemplo del uso de los consentimientos informados, que las personas tienen que saber de qué se trata la investigación para poder participar en ellas, en el fondo sabiendo a que se están enfrentando. Pero con el tema de las imágenes es más difícil, es como estar preguntando ¿puedo tomarles fotos o no? ¿Cómo lo ves ahí? Porque por un lado; es difícil para uno como Investigador; pero por otro lado uno podría pensar que las personas también tienen derecho a decidir, si quieren o no quieren que les saquen fotos.

Renée: ¡No claro! Es una paradoja, como todo. Estamos en un momento donde todo circula y todo circula por internet y definitivamente hay muy poco respeto a la fuente, al autor, al origen de las imágenes, hay una circulación excesiva de imágenes y hay también digamos; por un lado el peligro de la autoría, constantemente se está perdiendo, pero también hay una intromisión, a través de estas tecnologías, a la vida de los otros constantemente. Por otro lado, en términos de las publicaciones se aplican digamos estas leyes muy estrictas, que no se aplican en el mundo de la internet. Ahora, tienes razón que el individuo tiene totalmente derecho a decidir si quiere ser fotografiado o no. De hecho, muchas gentes que están de alguna manera acosadas por el lente de cámara, que además, también ese se reproduce a todos los teléfonos con cámaras ya. Porque de alguna manera se consideran parte ya del 
paisaje turístico que frecuenta turística. Acabo de estar en Bahía, entonces en el barrio del Pelourinho... que ahora es considerado patrimonio de la UNESCO, pues sacaron a los pobladores de esa zona y los trataron de embellecer para el turismo, porque era una zona decadente, peligrosa. Pero de todas maneras ese Pelourinho, ahora con grandes hoteles, resguardados de policías, iluminado... como si fuera Disneyland, está dentro del entorno del mismo barrio, a una cuadra cambia y permitieron que los antiguos pobladores... negros, bahianos, estén ahí siempre y cuando únicamente sean parte del paisaje folklórico. Entonces a mí me parece terrible, pero las mujeres tienen que estar vestidas de bahianas, como si fuera el siglo XVIII, para poder vender dulces, o poder vender comida Bahiana y los que pueden entrar al Pelourinho traen un chaleco de Guías turísticos y se mantienen ciertos elementos, que supongo que el propio gobierno, consideró importantes para mantener la vida o sea, aquellos que hacen arte, música, una serie de elementos. Pero obviamente la gente que está ahí, además que es una fuente de trabajo y que les permiten estar ahí, es asediada, constantemente por la fotografía de los visitantes. Estaba yo arriba en un edificio, cuando estaba una de las señoras bahiana, y llegaron a filmar un set... como de una película del siglo XVIII, con una mujer así de traje en las calles y al terminar el set yo estaba observando, se acercó ella y le dijeron que si no quería probar la comida bahiana y ella dijo que no, y entonces muchas gente se acercó a quererle tomar fotos a la que vendía la comida vestida de bahiana y lo que ella automáticamente hizo, tomo un papel con el que envolvía la comida y se lo puso en el rostro. Creo que ella tiene todo el derecho... además si nadie ni si quiera le está pidiendo su consentimiento, a taparse el rostro, hay otros que te cobran por la foto, incluso te asedian cobrándote por la foto. Muchos Indígenas, por ejemplo consideran que si le toman una fotografía les roban el alma y durante mucho tiempo los Indígenas de la trama Huicholes, pues era un problema muy serio, las industrias turísticas incrementaban además siempre el paisaje con el Indio ahí, no solamente vas a ver, sino el indio incorporado al paisaje, entonces eso hace una producción terrible de la persona como parte de un paisaje, que no tiene autoridad sobre si mismo, y que está ahí como inerme para que cualquiera se lleve la imagen, si es así, éticamente es terrible. Pero por otro lado, en términos de nuestro que hacer antropológico pues nos causa muchos problemas, porque de nuevo, como alguien que estudia una peregrinación o un ritual, va a poder pedir permiso a cada una de las personas que participa en ese ritual para poder tomar fotografías 
y el día que hagamos eso, pues se perdió realmente, también nuestra capacidad de registro. Yo creo que puedes pedir un permiso general por ejemplo, en el ritual, a quién coordina, a quien dirige, pero no puedes estar pidiendo. Y tiene que haber una ética también que uno sabe o te piden que hay momentos que no son fotografiables, que hay momentos que no tienes que fotografiar, pero esta cuestión de los derechos tenerlos firmados, también nos va a quitar la posibilidad de tener acceso a nuestras formas de trabajo antropológico. Claro, yo entiendo que a una persona le puedo pedir un per- miso como individuo, pero en esos eventos masivos grupales, le puedes pedir, a quien dirige el grupo, pero en los eventos masivos es muy difícil, es muy complicado y además nadie pide permiso, no es nomás del antropólogo, es imposible y el problema es que después de la publicación te digan "esto no puede ir porque no tienes el permiso de las 50 personas que aparecen ahí" y porque las reglas se ponen sin criterio, o sea se hace norma y te pone a todos por igual. A mí me parece que le quitaría posibilidades a la Antropología, igual que lo de la entrevista, si yo te hago a ti una historia de vida obviamente además tengo tu consentimiento, es muy difícil que yo te hable de mi vida y me siente con alguien 50 horas sin darte mi consentimiento... pero si yo voy haciendo otra vez, en un ritual entrevistas... ¡es que! tú dices "me permite entrevistarlo", pero yo no tengo un consentimiento escrito y firmado.

Pamela: ¿y en términos de publicación?

Renée: Cada vez me lo están pidiendo más (...) A mi me hicieron sacar de un texto que yo escribí, sobre la danza en una peregrinación las entrevistas que eran mayor de cuatro reglones.

Pamela: ¿Las citas?

Renée: Las citas textuales, o que les quitara que eran citas textuales. Entonces las tuve que reducir a tres o nada más decir "alguien dijo" y no citara textualmente. A mí me pasa que esto le va a quitar precisión y frescura a nuestro oficio de Antropología. Ahora el que las imágenes tienen autoría, tienen autoría y yo creo que eso es importante. Yo creo que se tiene que ver si es un close up, creo que sí, tienes que tener la autorización de esa persona,

Iluminuras, Porto Alegre, v. 14, n. 34, p. 375-393, ago./dez. 2013 
pero además es muy difícil, porque incluso esa persona puede no estar viendo la fotografía, puede que no le guste. Me acuerdo por ejemplo; hubo una vez una feria del Arte internacional en Guadalajara y había una mujer que se había hecho cirugías, cirugías para hacerse la cara como un gato, se llamaba Orlan ahí los periodistas, fueron rápido a tomarle fotografías, porque era además el evento, la mujer esta Francesa Orlan ella, se creía una Obra de Arte viva y que ella había hecho de su cuerpo, de su rostro una verdadera Obra de Arte. Entonces, uno de los periódicos locales le tomó una fotografía y osó en publicarla y ella demandó por 100 mil dólares, porque esa fotografía era su Abra de Arte y esa costaba 100 mil dólares... es muy complicado. Si tú estás del otro lado, del lado del periodista, además como asumes eso, es muy complejo, te parece un abuso. Yo creo que el problema siempre de estas nuevas situaciones es poner como norma general todas las cosas. Efectivamente también hay situaciones donde si se transgrede al individuo, como en el caso de la bahiana que no quería ser fotografiada y se puso un papel en la cara, o muchos indígenas que se tapan la cara y el turista está así (....) a encontrarlos, es también violentar la intimidad de alguien y además construir al sujeto en objeto... eso es terrible. En cambio hay otra gente que le encanta, que baila en el carnaval y al revés de la cámara, le bailan a la cámara. Entonces no necesitas pedirle un permiso, si lo que ella quiere es exactamente ser exhibida. Pero hay otra gente que no quiere ser exhibida, entonces como saber, o como llegar a eso. Porque también la fotografía crea la necesidad de muchos de exhibirse, a muchísima gente ven una cámara que está filmando la televisión y van ahí... o sea ¡ellos quieren salir! Eso también es un hecho, y hay quien no quiere salir.

\section{Pamela: ¿En México te piden consentimiento?}

Renée: En México ahorita, lo que si nos piden, obviamente, los derechos de autor para publicar las imágenes. En ninguna publicación tú puedes usar una imagen si no cuentas con la autorización firmada de los derechos de autor, pero no nos están pidiendo hasta ahorita derechos, sobre lo que fotografíes, hasta ahorita no... pero yo sé que en los Estados Unidos ya lo están haciendo en algunos casos, porque por lo mismo, como en el caso de Orlan quien asume una demanda así 100 mil. Imagina también el pobre fotógrafo, no tiene con qué pagar 100 mil dólares y la mujer además se dejaba fotografiar. Ahí también hay un 
juego del otro lado de transgresión ética. Ponte un letrero y di "cuesto 100 mil pesos la fotografía" y no lo permitas para no demandar, o sea ¡es complicado!. Por eso te pongo las situaciones, me parece que no puedes decir una sola cosa porque es complicado. Yo creo que ahí hay un juego de distintas situaciones, y que incluso, el problema es que, cuando se regulan cosas muchas veces no se atienden las situaciones.

Pamela: Un último tema Renée, eso que hablábamos con Ronaldo, sobre las diferencias o las semejanzas que tú puedes advertir entre México y Brasil, sobre la Antropología, el estudio de las imágenes.

Renée: Yo creo que la Antropología en México estuvo durante muchos, o en su inicio muy ligada a la producción de un sentido nacional y de colocar el tema Indígena y el del Campesinado, que en México fue muy importante. Yo creo que eso en Brasil, no tiene la importancia que tuvo en México, el tema del campesinado, como parte de la identidad revolucionaria Mexicana. Durante mucho tiempo los antropólogos estuvieron muy vinculados en la producción de una simbología, un discurso y constitución y unos programas de educación sobre todo enfocados en estos dos temas; los Indígenas y los campesinos. Lo que muchas veces iba relacionado pero no siempre, hay campesinos no Indios, pero la mayoría de los indígenas eran campesinos, vivían la condición campesina. Hasta los años 80 este fue el tema principal de la Antropología y después se empieza a desarrollar una Antropología urbana, que yo creo que ha sido muy importante. En México, a diferencia de Brasil el estructuralismo francés no tiene mucha cabida y aquí si LéviStrauss tiene un peso, hizo escuela y sigue teniendo un peso muy importante, en las formas de analizar, de interpretar. En cambio allá hubo, por un lado una corriente muy fuerte del marxismo estructuralista, el estructuralismo histórico marxista que venía de una escuela Española de Antropólogos republicanos que se refugiaron en México y que fueron así como los grandes padres de la Antropología en México, y por otro lado la escuela Inglesa Funcionalista. Esas fueron y siguen siendo, yo creo, las dos modalidades más fuertes, que marcan los modos de hacer Antropología en México. Yo aquí en Brasil, veo mucho más presencia del estructuralismo francés que te podría decir que hay dos personas en México que hacen ese tipo de trabajo, o sea, no es la forma de hacer Antropología. Ahora si bien en 
México hay y se han ido ampliando los temas de la Antropología, yo veo más temas, y sobre todo con una apertura a temas más emergentes o más nuevos aquí en Brasil que en México. A mí me llama la atención cuando les pregunto “y qué estas estudiando” y bueno los temas son totalmente muy novedosos desde; cuestión de culto al cuerpo, toda la cuestión de la sexualidad, yo creo que con una apertura de temas muy amplios, la cuestión de la Antropología Médica allá, por ejemplo esta más enfocadas a las formas de medicina tradicional y la forma de medicina institucional, en cambio acá ya están en el debate de las nuevas tecnologías de la Medicina. Yo siento que aquí hay como, una especie de apertura a nuevos debates que todavía no están presentes, como tal en México.

Pamela: ¿Y ves algo que allá este, que acá no este?

Renée: Yo creo que tienen bueno, obviamente además es una población donde lo Indígena tiene más presencia y el tema de la Antropología Étnica yo creo que es mucho más desarrollado en México que aquí, claro que aquí hay la Antropología de los pueblos nativos, de los pueblos ¿Cómo le llaman aquí?

\section{Pamela: De la Amazonas}

Renée: Amazónicos, pero es muy distinto, porque también son pueblos muy distintos, el Indio es otra cosa y tiene otro lugar en la conformación de identidad nacional de uno y otro País. Allá el Indio es parte de lo que nutre, una identidad nacional, con un pasado, un pasado trabajado como baluarte de una Nación hecha donde fue un Imperio Indígena, como el Perú, y eso es muy importante... eso es lo que más yo creo que marca una diferencia enorme.

Pamela: Y esta apertura a temas nuevos ¿a que crees tú que se debe?

Renée: A la realidad que aquí tienen, por ejemplo en México uno de los temas muy importantes es el de la migración, que es una realidad muy complicada en México. Entonces por ejemplo, la migración actualmente es transversal a casi todos los temas,

Iluminuras, Porto Alegre, v. 14, n. 34, p. 375-393, ago./dez. 2013 
transversal a la Religión, es transversal a la Antropología Medica, es transversal a la Antropología que tiene que ver con las Políticas Públicas ¿por qué?, porque ahorita para nosotros es el gran tema nacional...y todo esta ahorita atravesado por la violencia, por el narcotráfico, por la migración. Obviamente eso te va marcando como un tópico no nomas en la Antropología, en la Demografía, en la Biología, en la Ciencias Sociales, en la Historia, se va imponiendo como tópico. Cosa que aquí obviamente la migración no tiene el mismo lugar, la migración internacional no tiene el lugar, ni la misma perspectiva que tiene en México, los estudios de frontera allá tiene una relevancia enorme para el momento que vivimos en la actualidad, entonces yo creo que también, la Antropología va considerando tópicos hegemónicos y maneras de actuar dependiendo del lugar que ocupan, las problemáticas Sociales, Políticas y Culturales en cada País. A mí me gusta mucho enterarme de la riqueza de temas, que yo desde México ni me imaginaria, que se están estudiando. Lo otro que me gusta mucho es algo que nosotros mismos los mexicanos lo verbalizamos y es que los mexicanos no sabemos discutir y eso es un problema...

\section{Pamela: ¿Cómo así?}

Renée: No existe discusión porque culturalmente pensamos que eso es un pleito, por eso a mí me da mucho gusto cuando voy a Argentina, cuando voy a Brasil, ver que puede existir la capacidad de una discusión fuerte, una discusión formativa, pero que no es una agresión personal, y que eso se da y ayuda mucho a la producción de ideas. Eso en México, aunque nosotros lo decimos, estamos consientes, pero no podemos traspasar esa parte cultural. Es muy difícil la discusión y aquí me da mucho gusto ver eso. Incluso en las revistas se abren espacios de debates y los debates son debates, se debaten ideas, se debaten formas de estudiar, se debaten metodologías. Yo creo que eso es algo, muy enriquecedor de la Antropología Brasileña, o lo veo yo así verdad, por nuestra propia carencia... y me impresiona la cantidad de antropólogos que hay. Yo creo que la Antropología Brasileña, debido a que tiene tanto la influencia francesa como la funcional, es una de las Antropologías más ricas del mundo y además es muy libre. No es una Antropología que busque las ortodoxias, es creativa y los estudiantes tú los ves, que la Etnografía realmente es parte de su vida diaria. En cambio en México, por ejemplo un estudiante se le da un 
periodo, tiene un año para irse a trabajo de campo... pero es algo como un periodo que irrumpe, y acá lo veo como que la Etnografía es parte de su que hacer cotidiano incorporado en su vida, hay algo hay algo ahí, que también veo diferencia.

Pamela: ¿Algo que quieras agregar o quieras decir, o precisar?

Renée: No, mas bien, si fui muy confusa en algo, tú me dices porque yo no...

Pamela: ¡No, no! Fue una muy buena conversación...muchas gracias.

Recebido em: 15/09/2013

Aprovado em: 10/10/2013 